\title{
Primary oculocerebral lymphoma
}

INSERM

\section{Source}

INSERM. (1999). Orphanet: an online rare disease and orphan drug data base. Primary oculocerebral lymphoma. ORPHA:279897

Primary oculocerebral lymphoma is a rare, primary, organ-specific, extranodal nonHodgkin's lymphoma (typically diffuse large B-cell lymphoma), simultaneously affecting the intraocular compartments (retina, vitreous, optic nerve, uvea and others) and the central nervous system (commonly the cerebellum, spinal cord or pia mater). The presenting symptoms vary depending on the localization of the tumor and may include vitreous floaters or blurred vision, raised intracranial pressure (headache, vomiting, papilledema) and/or focal neurological deficits. 